\title{
From Citizen Science to Policy Development on the Coral Reefs of Jamaica
}

\author{
M. James C. Crabbe \\ Institute of Biomedical and Environmental Science Technology and Faculty of Creative Arts, Technologies and Science, \\ University of Bedfordshire, Park Square, Luton LU1 3JU, UK \\ Correspondence should be addressed to M. James C. Crabbe, james.crabbe@beds.ac.uk
}

Received 2 November 2011; Revised 30 November 2011; Accepted 6 December 2011

Academic Editor: Richard Stafford

Copyright ( $) 2012$ M. James C. Crabbe. This is an open access article distributed under the Creative Commons Attribution License, which permits unrestricted use, distribution, and reproduction in any medium, provided the original work is properly cited.

This paper explores the application of citizen science to help generation of scientific data and capacity-building, and so underpin scientific ideas and policy development in the area of coral reef management, on the coral reefs of Jamaica. From 2000 to 2008 , ninety Earthwatch volunteers were trained in coral reef data acquisition and analysis and made over 6,000 measurements on fringing reef sites along the north coast of Jamaica. Their work showed that while recruitment of small corals is returning after the major bleaching event of 2005, larger corals are not necessarily so resilient and so need careful management if the reefs are to survive such major extreme events. These findings were used in the development of an action plan for Jamaican coral reefs, presented to the Jamaican National Environmental Protection Agency. It was agreed that a number of themes and tactics need to be implemented in order to facilitate coral reef conservation in the Caribbean. The use of volunteers and citizen scientists from both developed and developing countries can help in forging links which can assist in data collection and analysis and, ultimately, in ecosystem management and policy development.

\section{Introduction}

Coral reefs throughout the world are under severe challenges from a variety of anthropogenic and environmental factors including overfishing, destructive fishing practices, coral bleaching, ocean acidification, sea-level rise, algal blooms, agricultural run-off, coastal and resort development, marine pollution, increasing coral diseases, invasive species, and hurricane/cyclone damage [1-3]. It is the application of citizen science to help generation of scientific data and capacity-building, and so underpin scientific ideas and policy development in the area of coral reef management, that are explored in this paper, concentrating on Jamaican coral reefs.

The "compulsive" appetite for increasing mobility [4] allied to a social desire for extraordinary "peak experiences" [5] has led to the modern "ethical consumer" for tourism services $[4,6]$ derived from the "experiential" and "existential" tourist of the 1970s [7]. Several organisations have taken the concept of ecotourism further to embracing tourism with citizen science, whereby the tourist gets to work on research projects under the supervision of recognised researchers.
Several organisations worldwide have developed citizen science programmes. The drivers behind these activities vary significantly between scientific studies, education, and/or getting the public more engaged and raising awareness of the natural environment. The overall driver cannot only determine the type, quality, and quantity of data required but also the level of volunteer expertise needed. Three organisations that have developed citizen science with tourism are the Earthwatch Institute, (http://www.earthwatch.org/), Operation Wallacea (http://www.opwall.com/), and Coral Cay Conservation (http://www.coralcay.org/). All are international environmental charities, working with a wide range of partners, from individuals who work as conservation volunteers on research teams through to corporate partners (such as HSBC with Earthwatch), governments, and institutions. Research volunteers work with scientists and social scientists around the world to help gather data needed to address environmental and social issues. It is the long-term strategy of these organisations combined with their citizen science funding models that underpins their successes; they are "in for the long haul" and can effect 
conservation in a different way to a standard 3-year research grant. Key elements are developing projects that can be used by volunteers and verifying the scientific information in a statistically significant way. This paper shows how an Earthwatch programme using volunteers on coral reefs generated scientific information which was used to inform management strategies in Jamaica.

\section{Materials and Methods}

2.1. Training of Volunteers. All volunteers were SCUBA divers of at least PADI Open Water standard. Training took place at the Discovery Bay Marine Laboratory, Jamaica, and consisted of lectures and interactive discussions covering scleractinian coral biology and taxonomy, coral recognition, data measurements and analysis, and health and safety. Volunteers all had to accomplish open water diving tests, and coral recognition tests in the field, after studying coral taxonomy books and passing land-based tests.

2.2. Reef Sites. Four randomly located transects, each $15 \mathrm{~m}$ long and separated by at least $5 \mathrm{~m}$, were laid at $5-8.5 \mathrm{~m}$ depth at each of five sites on the North coast of Jamaica near Discovery Bay: Rio Bueno ( $\left.18^{\circ} 28.805^{\prime} \mathrm{N} ; 77^{\circ} 21.625^{\prime} \mathrm{W}\right)$, M1 ( $\left.18^{\circ} 28.337^{\prime} \mathrm{N} ; 77^{\circ} 24.525^{\prime} \mathrm{W}\right)$, Dancing Ladies ( $18^{\circ}$ $\left.28.369^{\prime} \mathrm{N} ; 77^{\circ} 24.802^{\prime} \mathrm{W}\right)$, Dairy Bull $\left(18^{\circ} 28.083^{\prime} \mathrm{N} ; 77^{\circ}\right.$

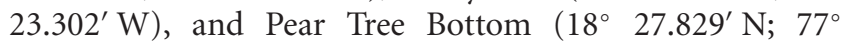
$\left.21.403^{\prime} \mathrm{W}\right)$. These sites were chosen as being workable by volunteers, as they were with 20 min boat ride from the Discovery Bay Marine Laboratory, where all volunteers stayed. Sites had been studied before over a number of years by marine scientists from many countries. GPS coordinates were determined using a hand-held GPS receiver (Garmin Ltd., UK).

2.3. Citizen Science Data Collection. Corals $2 \mathrm{~m}$ either side of the transect lines were photographed for archive information, and surface areas were measured with flexible tape as described previously using SCUBA [8-10]. Depth of samples was between 5 and $8.5 \mathrm{~m}$, to minimise variation in growth rates due to depth [11]. To increase accuracy, surface areas rather than diameters of live nonbranching corals were measured $[8,9]$. Sampling was over as wide a range of sizes as possible. Colonies that were close together $(<50 \mathrm{~mm})$ or touching were avoided to minimise age discontinuities through fission and altered growth rates [12-14]. In this study Montastrea annularis colonies were ignored, because their surface area does not reflect their age [12], and because hurricanes can increase their asexual reproduction through physical damage [13]. Overall, over 6,000 measurements were made on over 1,000 coral colonies, equally distributed between the sites for species and numbers of colonies.

This work was conducted at Discovery Bay during July 15-31 and December 19-30 in 2000, March 26-April 19 in 2002, March 18-April 10 in 2003, July 23-August 21 in 2004, July 18-August 13 in 2005, April 11-18 in 2006, December 30 in 2006-January 6 in 2007, and July 30-August 16 in 2008. Surveys were made at the same locations at the same sites each year. Data from ninety volunteers was used over this period.

2.4. Storm Severity. Data on storm severity as it impacted the island was obtained from UNISYS (http:// weather.unisys.com/hurricane/atlantic/), the NOAA hurricane site (http://www.nhc.noaa.gov/pastall.shtml). Information on bleaching was obtained from the NOAA coral reef watch site (http://coralreefwatch.noaa.gov/satellite/current/ sst_series_24reefs.html).

2.5. Data Analysis. Data analysis on corals was using ANOVA. Skewness (sk, [15]) was used to estimate the distribution of small and large colonies in the coral populations around Discovery Bay in Jamaica. In a normal distribution, approximately $68 \%$ of the values lie within one standard deviation of the mean. If there are extreme values towards the positive end of a distribution, the distribution is positively skewed, where the mean is greater than the mode (the mode is the value that occurs the most frequently in a data set) (right tail is longer). The opposite is true for a negatively skewed distribution, where the mean is less than the mode (left tail is longer). With regard to coral populations, negative skewness implies more large colonies than small colonies, while positive skewness implies more small colonies than large colonies.

\section{Results}

3.1. Coral Sizes and Growth. All the Jamaican sites showed some similarities in distribution of the size classes for the species studied between 2002 and 2008. However, there were differences between the different sites and between the different species studied at the sites. Skewness values (sk) were used to compare the distribution of the data between 2002 and 2008. For S. siderea, all sk values were positive, with more small colonies than in a normal distribution for 2002 and 2008, with little change between the dates (all sk values between 0.5 and 1.6). With $D$. labyrinthiformis colonies, there was a change from negative skewness in 2002 at Dairy Bull and Pear Tree Bottom, with more large colonies than in a normal distribution (sk values -0.25 and -0.006 , resp.) to smaller colonies than in a normal distribution in 2008 (sk values of 0.20 and 0.97 , resp.). There were no significant changes from 2002 to 2008 at the other sites, with positive sk values from 0.1 to 0.89 . M. meandrites colonies at Rio Bueno and Dairy Bull showed a relative decrease in the distribution of larger colonies from 2002 to 2008, with changes in sk values from -0.03 in 02 to 0.78 in 08 , and from -0.05 to 0.03 , respectively; the other sites all exhibited slightly positive sk values in both years from 0.1 to 0.5 . For Agaricia species, there was very little change between the years at all the sites, with sk values from 0.4 to 1.6. For $P$. astreoides, all values were positive for both years, with an increase in skewness at Rio Bueno from 0.2 to 2.6, showing a marked change in distribution towards the smaller colony sizes. At the other sites there were only small increases in sk values from 2002 to 2008, with Pear Tree Bottom showing 
a decrease in skewness from 0.9 to 0.6. D. strigosa colonies showed similar results to $P$. astreoides, all sk values being positive for 2002 and 2008, with an increase at Rio Bueno from 0.2 to 2.2 and at Pear Tree Bottom from 0.4 to 2.4; other sites showed similar sk values for 2002 and 2008 from 0.6 to 1.6. C. natans skewness changed from -0.07 to 0.68 at Rio Bueno from 2002 to 2008 (a decrease in larger colonies relative to a normal distribution) and at Dancing Ladies from -0.31 to 0.38 . Other sites showed similar skewness in 2002 and 2008 (sk values between 0.5 and 0.6), except Pear Tree Bottom, which exhibited near normal distribution of colonies about the mean for both 2002 and 2008 (sk values $<0.01)$. Interestingly, in 2005, the year after hurricane Ivan, the most severe storm to impact the reef sites over the study period, there was a slight reduction in the numbers of the smallest size classes, particularly notable at Dairy Bull.

In addition, our volunteer studies showed that radial growth rates $(\mathrm{mm} / \mathrm{yr})$ of non-branching corals calculated on an annual basis from 2000 to 2008 showed few significant differences either spatially or temporally along the North coast, although growth rates tended to be higher on reefs of higher rugosity and lower macroalgal cover [16].

3.2. Extreme Climate Events. The only extreme climate event that significantly impacted the Jamaican reef sites during the study period was the mass Caribbean bleaching event of 2005 [17]. Analysis of satellite data showed that there were 6 degree heating weeks ( $\mathrm{dhw}$ ) for sea surface temperatures in September and October 2005 near Discovery Bay, data which was mirrored by data loggers on the reefs.

3.3. Development of Coral Reef Action Plan. The coral size and growth data collected by the citizen scientists show that corals of above average size for their species at the sites studied lack resilience, particularly after the major bleaching event of 2005. Because of this, there is a need for different zones to have different levels of protection. To this end, the data was used in the development of an action plan for Jamaican coral reefs, presented to the Jamaican National Environmental Protection Agency, and described in Table 1.

\section{Discussion}

4.1. Citizen Science and Use of Volunteer Data. Citizen science and use of data measured by volunteers has been very helpful in a number of zoological areas, including amphibian population and biodiversity studies $[18,19]$, reporting invasive species [20], environmental monitoring [21], evolutionary change [22], marine species abundance and monitoring [2325], dryland mapping [26], and conservation planning [27, 28].

This study used self-selected as "Earthwatch volunteers", and all were SCUBA divers. Motivation was high in all the volunteers, as was the validity of the data presented by volunteers. A key element in citizen science is good training of volunteers. In the area of coral reef research described in this study, training was given in species recognition, quantitative measurement techniques and validation, and
TABLE 1: Seven-point action plan for Jamaican coral reefs.

(1) The reefs around Jamaica could be designated as the Jamaican Coral Reef Marine Park. This could include all the fringing reefs, seagrass beds, and mangroves from Negril to all along the north coast to the eastern tip of the island. On the south coast it could include Port Royal and Portland Bight. The advantage of this is that one can then consider protection of the Jamaican reefs as a whole. Another advantage is that climate change effects can be considered in a more holistic way

(2) There could be a single body, possibly the National Environment Protection Agency (NEPA), or a subset of NEPA, given authority to manage the Park

(3) There could be a statement drawn up on "protection and wise use" of the Park. Drawing up that statement should include all stakeholders, from fishermen through Industry and tourism to policy makers

(4) The Park could be managed using a "zoning" system. This has been valuable in a number of areas, not least the Great Barrier Reef. This will allow some areas to have greater restrictions (e.g., fishing, resort pollution, ship pollution) than others. Such zoning should help avoid the "tragedy of the commons". Zoning Plans define what activities can occur in which locations, both to protect the marine environment and to separate potentially conflicting activities

(5) Divisions into zones could be

General Use,

Conservation Park,

Habitat Protection,

Marine National Park,

Another zone might be a Buffer Zone, next to a Marine National Park

(6) Each zone should have at least one of the following: (i) Community Partnerships, (ii) Local Marine Advisory Committees, and (iii) Reef Advisory Committees. These bodies should be responsible for regulating their own area and should be responsible to the overall Marine Park Management body. They would also be responsible for community involvement and information

(7) Permissions within the zones (e.g., for tourism, fishing, etc.) would be given by the Jamaican Government, through NEPA

data analysis. Independent validation of volunteer data, once training had been given, was consistent with previous findings by other groups [29]. The validation of the data produced by the volunteers indicated that with appropriate training, data collection by citizen scientists is appropriate for scientific applications in marine biology.

4.2. Coral Health and Resilience. What is apparent from our studies is that despite the chronic and acute disturbances between 2002 and 2008, demographic studies indicate good levels of coral resilience on the fringing reefs around Discovery Bay in Jamaica (see also [30]). The bleaching event of 2005 resulted in mass bleaching but relatively low levels of mortality unlike corals in the US Virgin islands and Tobago where there was extensive mortality [17, 31], probably because of their greater degree heating week values. 
This data shows that while recruitment of small corals is returning after the major bleaching event of 2005 [32], larger corals are not necessarily so resilient and so need careful management if the reefs are to survive such major extreme events.

\subsection{From Information to Policy Development: Themes and} Tactics. Marine reserves are an important tool in the sustainable management of many coral reefs [33]. However, it is important that the reef ecosystems share regulatory guidelines, enforcement practices and resources, and conservation initiatives and management, underpinned by scientific research. An example of a single marine reserve is the Great Barrier Reef in Australia operated and managed solely by the Great Barrier Reef Marine Park Authority (GBRMPA). In contrast, the second largest barrier reef in the world, the MesoAmerican Barrier Reef, is bounded by four countries (Mexico, Belize, Guatemala, and Honduras), each with its own laws and policies. Here, a number of single and separated marine reserves exist along the barrier reef. In Belize we have successfully transferred scientific expertise in Belize to local volunteers to generate scientific evidence to underpin future management and conservation decisions, as judged, for example, by scientific findings on the impact of hurricanes on reefs in Belize, which showed that hurricanes and severe storms limited the recruitment and survival of nonbranching corals of the Mesoamerican barrier reef [10].

For Jamaica, the Action Plan developed (Table 1) was well received by managers of the National Environment Protection Agency (NEPA). It was felt by managers that this approach could link together the environment with tourism and business, so that environmental issues are seen as part of the way forward, not part of the problem, as has been all too evident in the past. Even if smaller Marine Protected Areas (MPAs) were developed around the island, the adoption of shared ownership of reef ecosystems was felt to be useful way to proceed.

In order to take this forward, it was felt necessary to develop a number of themes and tactics. In a separate capacity building exercise [34], for the MesoAmerican Barrier Reef in Sothern Belize, one officer from the Belize Fisheries Department, three senior officers from NGOs involved in managing Belize MPAs (TIDE, the Toledo Institute for Development and Environment; TASTE, the Toledo Association for Sustainable Tourism and Empowerment; and Friends of Nature), and a Facilitator (the author) from the UK developed six-month Personal/Professional Action Plans which involved

(a) tactics for leading, educating, and supporting issues regarding sustainable development of coral reefs;

(b) tactics for collaboration with other stakeholders to collectively influence policy decisions for coral reef conservation.

Discussion among the participants and facilitator resulted in the generation of a series of generic tactics to be adopted around a number of themes. These are enumerated in Table 2. Such themes and tactics may be
TABLE 2: Themes and tactics to facilitate conservation of coral reefs.

\section{Organisation and Management}

Tactic number 1: establish a key leader in the

Organization/Department to effectively manage the Marine reserves on a day-to-day basis

Tactic number 2: have a selected key leader provide general Terms of Reference of what is expected of staff and immediate/major stakeholders in order to easily facilitate the process of decision making

\section{Education}

Tactic number 1: financial resources need to be allocated for an education program. The program should focus on both broad and specific issues that may create friction among stakeholders in the process

Tactic number 2: a group consisting of community leaders and key/immediate stakeholders should be established to create ways and methods of educating different levels of stakeholders in the effectiveness of sustainable development in the marine parks

Tactic number 3: surveys need to be conducted to evaluate level of success and failure. Too often programmes have been formed and implemented but end results have not been evaluated. Surveys should be carried back to stakeholders for a presentation to establish further steps

\section{Support}

Tactic number 1: a well-put together presentation needs to be developed and be presented to the key authority that will have over-all say in the marine park(s). This will stress on the support needed to accomplish both the mission and vision statements and will have positive effects in sustainable development

Tactic number 2: nonmonetary incentives need to be established in order to have full support of stakeholders who would otherwise deter progress in sustainable development

\section{Policies}

Tactic number 1: establish a set of policies that is considered necessary for proper management of the marine reserves. Such policies will be established by all stakeholders involved

Tactic number 2: create an influencing program for stakeholders to adhere to such policies through an education/retreat program

Tactic number 3: establish exchanges with other organizations in capacity building in policy creation and effective implementation

useful in development of coral reef policies in the Caribbean and elsewhere.

\section{Conclusion}

The use of volunteers and citizen scientists from both developed and developing countries can help in forging links which can assist in data collection and analysis and, ultimately, in ecosystem management and policy development. There is much progress internationally in involving organisations to utilize citizen science effectively and efficiently (e.g., [35]).

A number of questions remain for the future, for example, assessing how citizen science could be used to 
better effect, for example, identifying the potential for citizen science to fill known data gaps, for example, gaps in marine and terrestrial taxonomies. In addition, we need greater understanding of where and how technology (software, statistics) can transform the quality and quantity of data from nonexperts, and how scientists can make best use of technology, for example, in using smart phone apps to identify and/or record species and measurements.

\section{Acknowledgments}

The author thanks the Earthwatch Institute, the Royal Society, and the Oak Foundation (USA) for funding, Mr. Anthony Downes, Mr. Peter Gayle, and the staff of the Discovery Bay Marine Laboratory for their invaluable help and assistance, to the two anonymous referees for their valuable comments which improved the manuscript, to E. Martinez, C. Garcia, J. Chub, L. Castro, J. Guy, and Earthwatch colleagues in Belize, and to many volunteers for their considerable help underwater during this project.

\section{References}

[1] T. A. Gardner, I. M. Côté, J. A. Gill, A. Grant, and A. R. Watkinson, "Long-term region-wide declines in Caribbean corals," Science, vol. 301, no. 5635, pp. 958-960, 2003.

[2] D. R. Bellwood, T. P. Hughes, C. Folke, and M. Nyström, "Confronting the coral reef crisis," Nature, vol. 429, no. 6994, pp. 827-833, 2004.

[3] M. J. C. Crabbe, E. E. L. Walker, and D. B. Stephenson, "The impact of weather and climate extremes on coral growth," in Climate Extremes and Society, H. F. Diaz and R. J. Murnane, Eds., pp. 165-188, Cambridge University Press, New York, NY, USA, 2008.

[4] P. Burns, "Tribal tourism-cannibal tours: tribal tourism to hidden places," in Niche Tourism: Contemporary Issues, Trends, Cases, pp. 101-110, Elsevier, Oxford, UK, 2005.

[5] A. Holden, Environment and Tourism, Routledge, London, UK, 2nd edition, 2008.

[6] D. Fennell, Ethical Tourism, Routledge, London, UK, 2006.

[7] E. Cohen, "A phenomenology of tourist experiences," Sociology, vol. 13, pp. 179-201, 1979.

[8] M. J. C. Crabbe, J. M. Mendes, and G. F. Warner, "Lack of recruitment of non-branching corals in Discovery Bay is linked to severe storms," Bulletin of Marine Science, vol. 70, no. 3, pp. 939-945, 2002.

[9] M. J. C. Crabbe and D. J. Smith, "Sediment impacts on growth rates of Acropora and Porites corals from fringing reefs of Sulawesi, Indonesia," Coral Reefs, vol. 24, no. 3, pp. 437-441, 2005.

[10] M. J. C. Crabbe, E. Martinez, C. Garcia, J. Chub, L. Castro, and J. Guy, "Growth modelling indicates hurricanes and severe storms are linked to low coral recruitment in the Caribbean," Marine Environmental Research, vol. 65, no. 4, pp. 364-368, 2008.

[11] M. Huston, "Variation in coral growth rates with depth at Discovery Bay, Jamaica," Coral Reefs, vol. 4, no. 1, pp. 19-25, 1985.

[12] T. P. Hughes and J. B. C. Jackson, "Do corals lie about their age? Some demographic consequences of partial mortality, fission, and fusion," Science, vol. 209, no. 4457, pp. 713-715, 1980.
[13] N. L. Foster, I. B. Baums, and P. J. Mumby, "Sexual vs. asexual reproduction in an ecosystem engineer: the massive coral Montastraea annularis," Journal of Animal Ecology, vol. 76, no. 2, pp. 384-391, 2007.

[14] R. Elahi and P. J. Edmunds, "Consequences of fission in the coral Siderastrea siderea: growth rates of small colonies and clonal input to population structure," Coral Reefs, vol. 26, no. 2, pp. 271-276, 2007.

[15] J. H. Zar, Biostatistical Analysis, Prentice-Hall, Upper Saddle River, NJ, USA, 4th edition, 1999.

[16] M. J. C. Crabbe, "Climate change and tropical marine agriculture," Journal of Experimental Botany, vol. 60, no. 10, pp. 2839-2844, 2009.

[17] C. M. Eakin, J. A. Morgan, S. F. Heron et al., "Caribbean corals in crisis: record thermal stress, bleaching, and mortality in 2005," PLoS One, vol. 5, no. 11, article e13969, 2010.

[18] A. Bonardi, R. Manenti, A. Corbetta et al., "Usefulness of volunteer data to measure the large scale decline of "common" toad populations," Biological Conservation, vol. 144, no. 9, pp. 2328-2334, 2011.

[19] D. Sewell, T. J. C. Beebee, and R. A. Griffiths, "Optimising biodiversity assessments by volunteers: the application of occupancy modelling to large-scale amphibian surveys," Biological Conservation, vol. 143, no. 9, pp. 2102-2110, 2010.

[20] T. Gallo and D. Waitt, "Creating a successful citizen science model to detect and report invasive species," BioScience, vol. 61, no. 6, pp. 459-465, 2011.

[21] C. C. Conrad and K. G. Hilchey, "A review of citizen science and community-based environmental monitoring: issues and opportunities," Environmental Monitoring and Assessment, vol. 176, pp. 273-291, 2011.

[22] J. Silvertown, L. Cook, R. Cameron et al., "Citizen science reveals unexpected continental-scale evolutionary change in a model organism," PLoS One, vol. 6, no. 4, article e18927, 2011.

[23] C. A. Ward-Paige, C. Pattengill-Semmens, R. A. Myers, and H. K. Lotze, "Spatial and temporal trends in yellow stingray abundance: evidence from diver surveys," Environmental Biology of Fishes, vol. 90, pp. 263-276, 2010.

[24] S. Goffredo, F. Pensa, P. Neri et al., "Unite research with what citizens do for fun: recreational monitoring of marine biodiversity," Ecological Applications, vol. 20, no. 8, pp. 21702187, 2010.

[25] P. G. Finn, N. S. Udy, S. J. Baltais, K. Price, and L. Coles, "Assessing the quality of seagrass data collected by community volunteers in Moreton Bay Marine Park, Australia," Environmental Conservation, vol. 37, no. 1, pp. 83-89, 2010.

[26] D. S. Turner and H. E. Richter, "Wet/dry mapping: using citizen scientists to monitor the extent of perennial surface flow in dryland regions," Environmental Management, vol. 47, no. 3, pp. 497-505, 2011.

[27] P. De Ornellas, E. J. Milner-Gulland, and E. Nicholson, “The impact of data realities on conservation planning," Biological Conservation, vol. 144, no. 7, pp. 1980-1988, 2011.

[28] D. B. Oscarson and A. J. K. Calhoun, "Developing vernal pool conservation plans at the local level using citizen-scientists," Wetlands, vol. 27, no. 1, pp. 80-95, 2007.

[29] P. J. Mumby, A. R. Harborne, P. S. Raines, and J. M. Ridley, "A critical assessment of data derived from coral cay conservation volunteers," Bulletin of Marine Science, vol. 56, no. 3, pp. 737751, 1995.

[30] M. James and C. Crabbe, "Coral resilience on the reefs of Jamaica," Underwater Technology, vol. 30, no. 2, pp. 65-70, 2011. 
[31] J. Mallela and M. J. C. Crabbe, "Hurricanes and coral bleaching linked to changes in coral recruitment in Tobago," Marine Environmental Research, vol. 68, no. 4, pp. 158-162, 2009.

[32] M. J. C. Crabbe, "Environmental effects on coral growth and recruitment in the Caribbean," Journal of the Marine Biological Association of the UK. In press.

[33] L. Cho, "Marine protected areas: a tool for integrated coastal management in Belize," Ocean and Coastal Management, vol. 48, no. 11-12, pp. 932-947, 2005.

[34] M. J. C. Crabbe, E. Martinez, C. Garcia, J. Chub, L. Castro, and J. Guy, "Is capacity building important in policy development for sustainability? A case study using action plans for sustainable marine protected areas in Belize," Society and Natural Resources, vol. 23, no. 2, pp. 181-190, 2010.

[35] "UK-Environmental Observation Framework, Workshop Report," pp. 45, 2011, http://www.ukeof.org.uk/documents/. ukeof-citizen-science-workshop-report.pdf. 

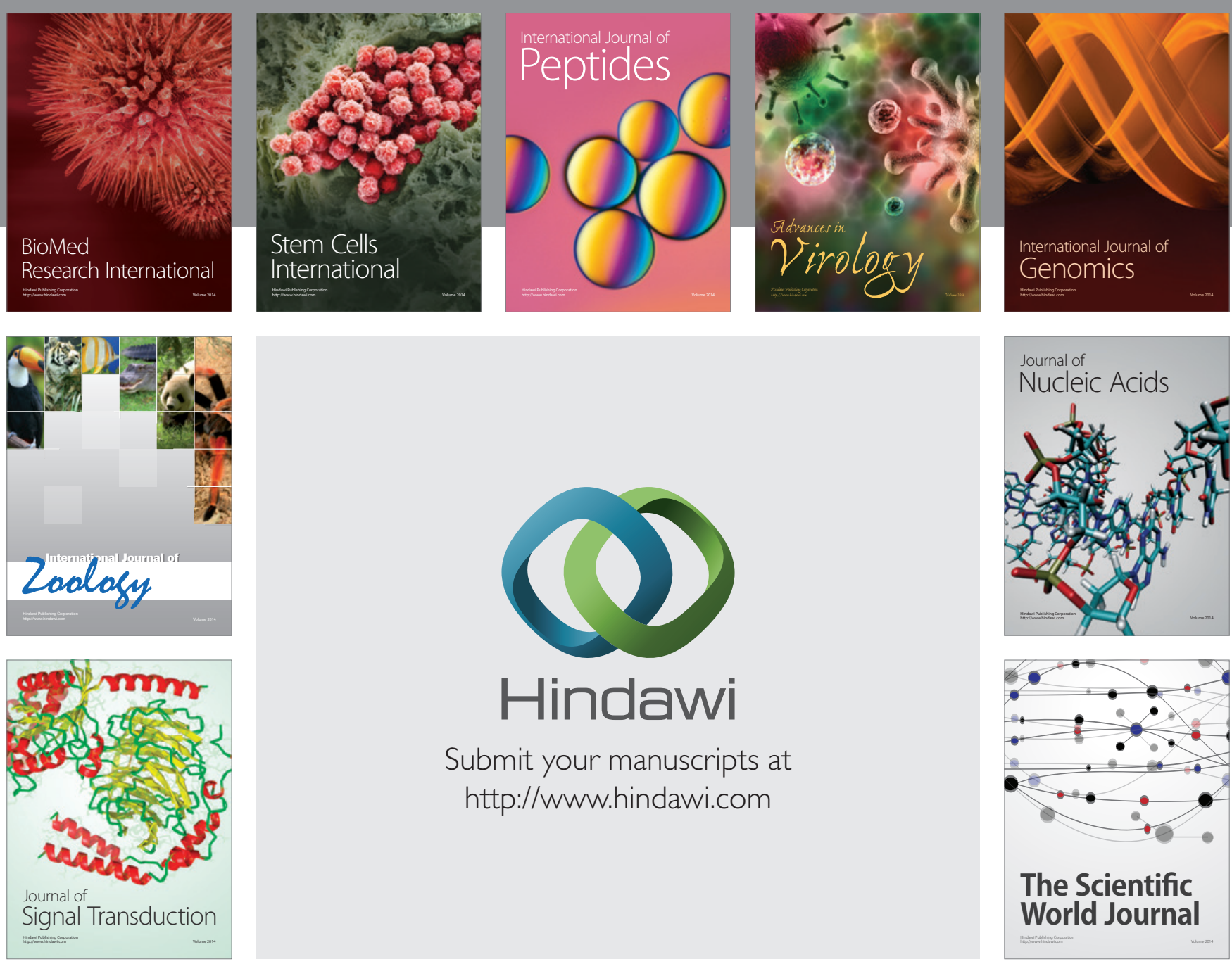

Submit your manuscripts at

http://www.hindawi.com
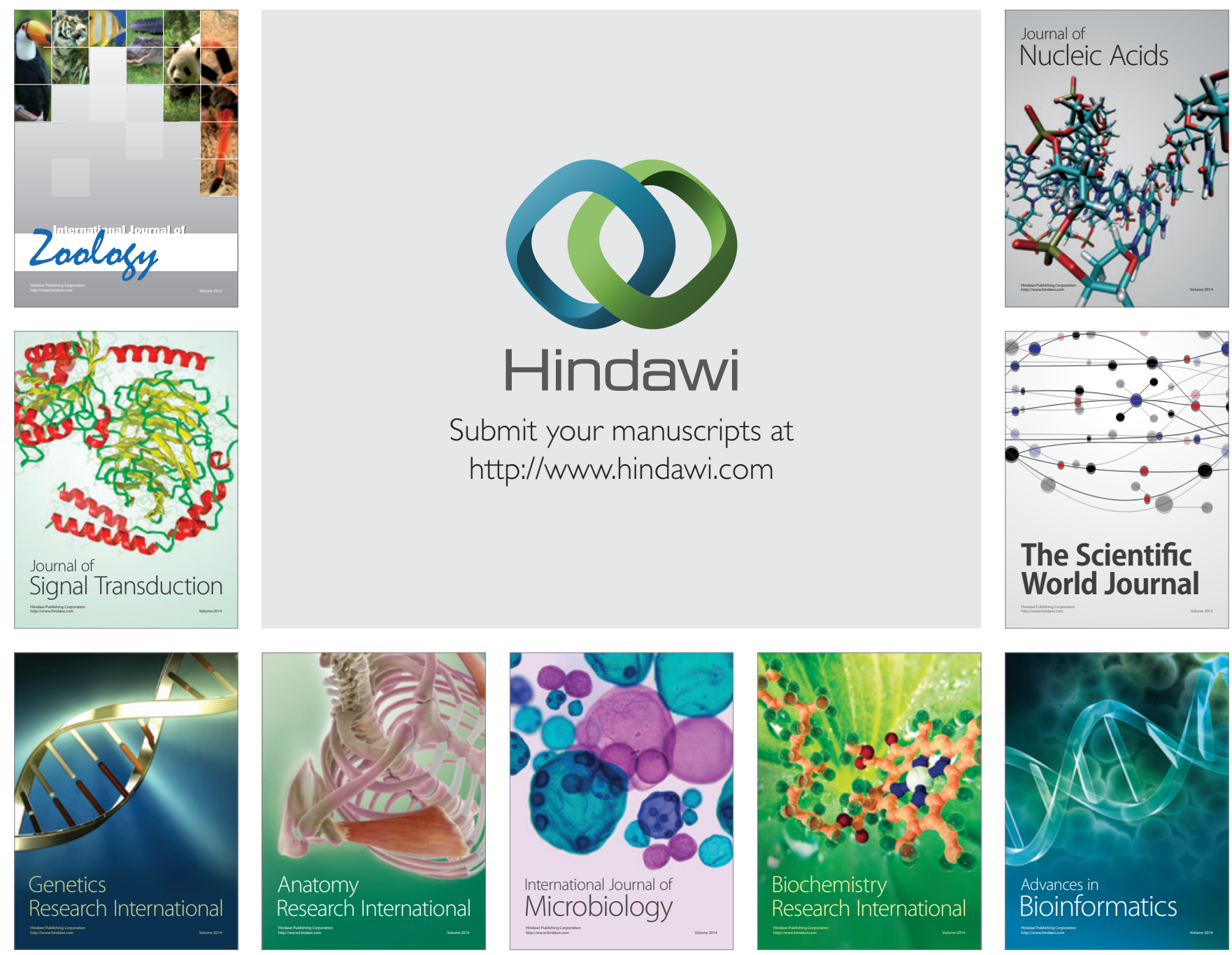

The Scientific World Journal
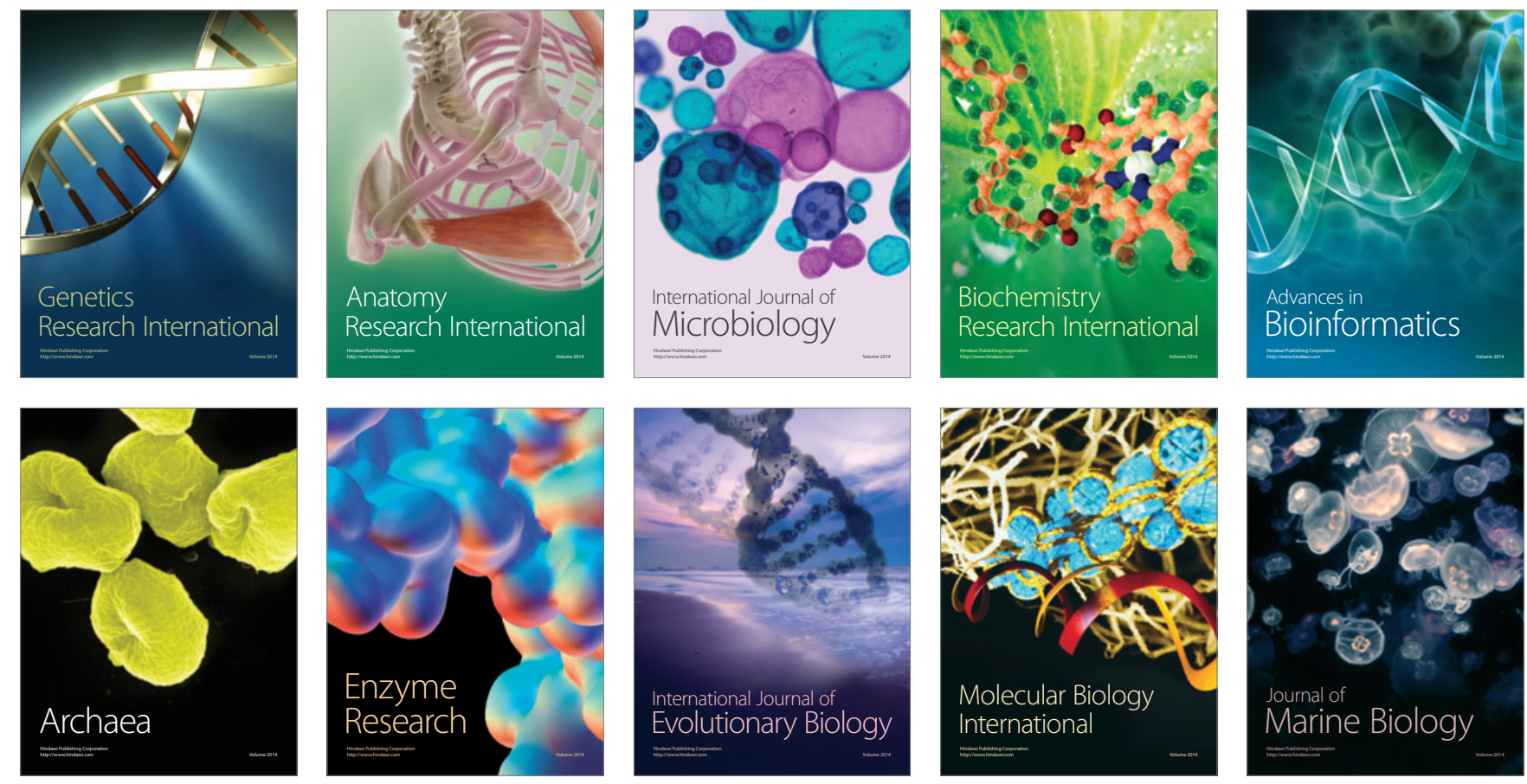